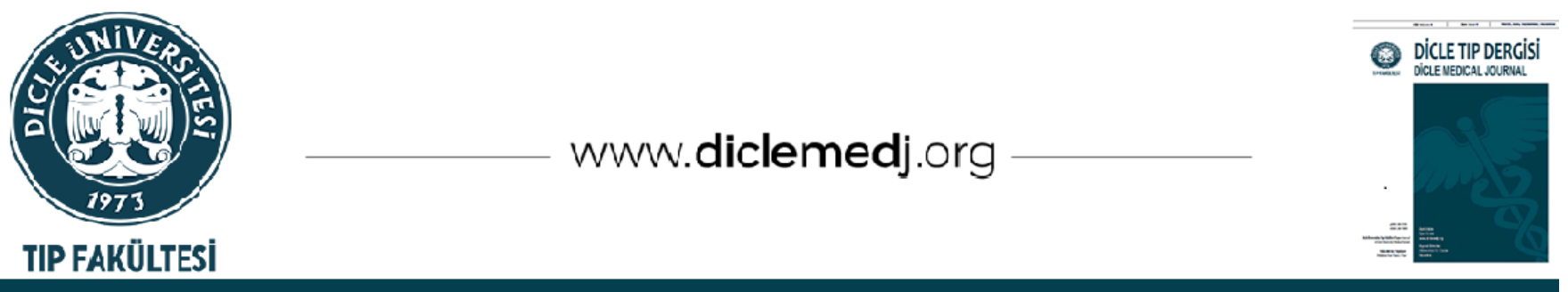

Original Article / Özgün Araştırma

\title{
Mutation Analysis of Beta-Thalassemia Major Patients and Their Parents in Diyarbakir Province, Turkey
}

\author{
Cemal Polat ${ }^{\text {i }}{ }_{1}$, Nuriye Mete ${ }^{D_{2}}{ }_{2}$ Murat Söker ${ }^{\text {iD }} 3$ \\ 1 Department of Biochemistry, Isparta City Hospital, Isparta, Turkey \\ 2 Department of Biochemistry, Faculty of Medicine, Dicle University, Diyarbakir, Turkey \\ 3 Department of Pediatric Hematology and Oncology, Faculty of Medicine, Dicle University, Diyarbakir, Turkey \\ Received: 25.10.2020; Revised: 11.01.2021; Accepted: 18.01.2021
}

\begin{abstract}
Objectives: In this study, beta-Thalassemia Major (BTM) diagnosed patients and their parents were subjected to DNA sequencing in order to confirm their diagnosis, improve their treatment and determine the mutation distributions of both patients and their parents.
\end{abstract}

Methods: A total of 90 people, BTM patients $(n=30)$ and their parents $(n=60)$, were included in the study. For all analyses, two blood samples were taken into EDTA-containing tubes from each of the patients and each of their parents. Complete blood count, hb variant and mutation analysis were studied, respectively.

Results: 8 types of mutation were determined: IVS-I-110 (G->A) 46.67\%, codon 8 (-AA) 16.67\%, IVS-II-1 (G->A) 11.67\%, codon 44 (-C) 10.00\%, IVS-II-745 (C->G) 5.00\%, IVS-I-1 (G->A) 3.33\%, IVS-I-5 (G->T) 3.33\% and -30 (T$>$ A) $3.33 \%$. Hb concentrations of $9.2 \pm 1.32 \mathrm{~g} / \mathrm{dL}$ and $\mathrm{Hb}$ variant levels of $\mathrm{HbA} 81.58 \% \pm 11.05$, $\mathrm{HbF} 10.44 \% \pm 11.54$ were found in patients with BTM who received transfusion therapy regularly. Typical hemogram count and $\mathrm{Hb}$ variants levels were seen in parents.

Conclusion: In our study, a similar distribution was identified throughout Turkey in terms of mutation. Mutations were classified in all the studied people. This study increased the detection percentage of undetermined mutations by the use of DNA sequencing. Thus a multi-centric coordinated study with high capacity will improve detecting these mutations and their effects on the disease.

Keywords: DNA sequence analysis, Thalassemia, Beta-Thalassemia, Mutation

DOI: $10.5798 /$ dicletip.887407

Correspondence / Yazıșma Adresi: Cemal Polat, Isparta City Hospital, Department of Biochemistry, Sanayi Mahallesi, 104. Cad. No: 51, 32200 Isparta, Turkey, e-mail: drcpolat@gmail.com 


\section{Diyarbakır İlinde Beta-Talasemi Majörlü Hastalar ve Ebeveynlerinde Mutasyon Analizi} Öz

Amaç: Bu çalışmada beta-Talasemi Majör (BTM) tanısı almış hastalar ve ebeveynlerinde; DNA dizi analizi yöntemiyle tanısının kesinleștirilmesi, tedavisine katkıda bulunulması ve mutasyon dağılımının tespiti amaçlanmıştır.

Yöntemler: Çalışmaya BTM'li hastalar $(n=30)$ ve ebeveynleri $(n=60)$ olmak üzere toplam 90 kişi dâhil edilmiştir. Tüm analizler için hastalar ve ebeveynlerinin her birinden iki adet EDTA ihtiva eden tüplere kan numunesi alınmıştır. Sırasıyla tam kan sayımı, Hb varyant ve mutasyon analizi çalışılmıştır.

Bulgular: IVS-I-110 (G->A) \%46.67, codon 8 (-AA) \%16.67, IVS-II-1 (G->A) \%11.67, codon 44 (-C) \%10.00, IVS-II745 (C->G) \%5.00, IVS-I-1 (G->A) \%3.33, IVS-I-5 (G->T) \%3.33 ve -30 (T->A) \%3.33 olmak üzere 8 çeşit mutasyon tespit edildi. Düzenli olarak transfüzyon tedavisi alan BTM'li hastalarda Hb konsantrasyonu $9.2 \pm 1.32 \mathrm{~g} / \mathrm{dL}$ ve $\mathrm{Hb}$ varyant düzeyi $\mathrm{HbA} \% 81.58 \pm 11.05, \mathrm{HbF} \% 10.44 \pm 11.54$ olarak tespit edilmiştir. Ebeveynlerde ise tipik hemogram sayımı ve $\mathrm{Hb}$ varyant düzeyleri görüldü.

Sonuç: Çalışmamızda mutasyon açısından Türkiye geneline benzer bir dağılım tespit edildi. Çalışılan tüm kişilerde mutasyonlar tasnif edildi. Bu çalışma DNA dizi analizi yönteminin kullanımına bağlı olarak saptanamayan mutasyonların belirlenme oranını artırmıştır. Buna bağlı olarak yüksek kapasiteli çok merkezli koordine bir çalışma ile bu mutasyonların ve bunların hastalığa etkisinin belirlenmesini geliştirecektir.

Anahtar kelimeler: DNA dizi analizi, Talasemi, Beta-Talasemi, Mutasyon.

\section{INTRODUCTION}

Beta-Thalassemia (BT) is a generally autosomal recessive disorder caused by mutations of the beta-globin gene which is located on the short arm of chromosome 11 resulting in the reduction $\left(\beta^{+}\right)$or absence $\left(\beta^{0}\right)$ of the beta-globin chain synthesis ${ }^{1,2}$. Although BT is a worldwide common disease, it is most frequently seen in the population of the Mediterranean, MiddleEast, Transcaucasus, Central Asia, Indian subcontinent, and Far East. Highest incidences were reported from Cyprus (14\%), Sardinia (12\%) and Southeast Asia. About 1.5\% of the world's population is BT carrier ${ }^{3,4}$. BTT frequency in Turkey is approximately $2.1 \%$, while in some regions the frequency increases up to $10 \%{ }^{5}$. According to its clinical and hematological severity, BT is categorized in three groups: Beta-Thalassemia Trait (BTT), Beta-Thalassemia Intermediate (BTI) and BetaThalassemia Major (BTM). Except for rare dominant forms, BTT is mostly heterozygous whereas BTI and BTM are homozygous or seen in combined heterozygous forms. BT patients are diagnosed based on clinical and laboratorical findings. As for the laboratory diagnosis; complete blood count, qualitative and quantitative $\mathrm{Hb}$ analysis [electrophoresis, high performance liquid chromatography (HPLC)] and PCR-based molecular tests for mutation analysis are routinely performed ${ }^{6-8}$. Worldwide, more than 250 different mutations have been detected so far by molecular analysis ${ }^{9}$. In Turkey, more than 40 different BT mutations have been identified showing differences in the distribution of mutation types between different areas of Turkey ${ }^{10}$. Although there are gene therapy studies no definite therapy exists besides bone marrow transplantation in BT so far ${ }^{11-13}$.

BT is one of the common genetic diseases in our country and region as well as in the world. Nowadays, DNA sequence analysis is a very sensitive method in determining the diagnosis of BT and the type of mutation. In this study, patients with BTM diagnosed and / or treated in our hospital and their parents were subjected to DNA sequencing in order to confirm the 
diagnosis, improve their treatment and determine the mutation distributions of both patients and their parents.

\section{METHODS}

Patients $(n=30)$ with diagnosed BTM, who underwent therapy and /or follow-up in the Pediatric Hematology and Oncology Division at Dicle University Faculty of Medicine between January and February 2013 and their parents $(n=60)$ were included in the study. This study was performed in accordance with the Declaration of Helsinki. For our work, we received approval from the ethics committee of the Faculty of Medicine at Dicle University (Decision number: 739/13.11.2012). No distinction was made between age and gender among the individuals included in the study. Blood samples were taken from the patients before transfusion of erythrocyte suspension. Two EDTA- containing tubes (BD Vacutainer®) SSTTMII Advance) of blood samples were taken from the patients and from each of the parents. One of the EDTA tubes was used for complete blood count by the flow cytometry method (Cell Dyn 3700; Abbott Laboratories, Abbott Park, IL, USA) and for measuring $\mathrm{Hb}$ variant levels via HPLC (Agilent 1100 series; Agilent Technologies, Waldbronn, Germany). The other EDTA-tubes were stored at $-20^{\circ} \mathrm{C}$ for about 6 months for molecular gene analysis. In our molecular diagnostic laboratory, DNA isolation from EDTA complete blood count samples was carried out using the commercial kit procedure (Macherey-Nagel, Düren, Germany). Samples which underwent DNA-isolation were stored at $-20^{\circ}$ C. DNA samples of the patients were amplified by the primers from a commercial kit (GML, Switzerland) using GeneAmp PCR System 9700 (Applied Biosystems, USA). Afterwards PCR-product purification was performed with the ExoSAP-IT (GML, Switzerland) reagent. Big Dye ${ }^{\circledR}$ Terminator v3.1 cycle sequencing kit
(Applied Biosystems, Foster City, CA, USA) was used for sequence reaction. Mutation analysis was carried out by the automated sequence device ABI Prism 310 Genetic Analyzer (Applied Biosystems, Foster City, CA, USA). Mutations were detected with SeqScape Software v2.6 program.

\section{Statistical Analysis}

Statistical analysis of the data was performed using SPSS 15.0 (SPSS Inc. Chicago, IL, USA) version package program as well as Microsoft Excel 2010 version. Descriptive statistics was applied for the analysis of the data of the study. For quantitative variables mean \pm standart deviation and median(minimum-maximum) values were used whereas number and percentage ratios were used for qualitative findings.

\section{RESULTS}

In our study, patiens with BTM regularly (3-4 week/period) received erythrocyte suspension transfusions. Data gained from BTM patients constituted of data before getting transfusion. Statistical data of the hematological analysis and $\mathrm{Hb}$ variant levels obtained from BTM patients and their parents are shown in table I and table II. One parent (mother and father) and one mother were excluded from the $\mathrm{Hb}$ variant statistics due to extremely abnormal $\mathrm{HbF}$ value and $\mathrm{HbA} 2$ value, respectively.

Mutation variants, mechanisms, phenotypic features and frequencies detected by DNA sequence analysis in BTM patients and their parents are shown in table III. In total, according to their frequency, 8 different mutations were detected as follows: IVS-I-110 (G->A) 46.67\%, codon 8 (-AA) 16.67\%, IVS-II-1 (G->A) 11.67\%, codon 44 (-C) 10.00\%, IVS-II-745 (C->G) 5.00\%, IVS-I-1 (G->A) 3.33\%, IVS-I-5 (G->T) 3.33\% and $-30 \mathrm{~T}(\mathrm{~T}->\mathrm{A}) 3.33 \%$ (table III). 
Table I: Statistics of hematological analysis in BTM patients and their parents.

\begin{tabular}{|c|c|c|c|c|c|}
\hline & Statistics & $\begin{array}{l}\text { RBC } \\
\text { (M/uL) }\end{array}$ & $\begin{array}{l}\mathrm{Hb} \\
(\mathrm{g} / \mathrm{dL})\end{array}$ & $\begin{array}{l}\text { MCV } \\
\text { (fL) }\end{array}$ & $\begin{array}{l}\text { MCH } \\
\text { (pg) }\end{array}$ \\
\hline \multirow{2}{*}{ Patient $(n=30)$} & Mean $\pm S^{1}$ & $3.26 \pm 0.46$ & $9.2 \pm 1.32$ & $78.9 \pm 5.47$ & $28.3 \pm 1.65$ \\
\hline & Median (min- $\left.\max ^{2}\right)$ & $3.30(2.39-4.26)$ & $9.0(6.8-12.3)$ & $79.4(59.5-86.4)$ & $28.5(22.7-30.7)$ \\
\hline \multirow{2}{*}{ Father $(n=30)$} & Mean $\pm S D^{1}$ & $6.34 \pm 0.75$ & $13.5 \pm 1.16$ & $63.8 \pm 5.75$ & $21.4 \pm 1.49$ \\
\hline & Median (min- $\max ^{2}$ ) & $6.39(3.95-7.97)$ & $13.4(10.2-16.8)$ & $63.3(55.8-83.8)$ & $21.2(19.1-25.9)$ \\
\hline \multirow{2}{*}{ Mother $(n=30)$} & Mean $\pm S^{1}$ & $5.42 \pm 0.46$ & $11.2 \pm 1.05$ & $62.6 \pm 3.57$ & $20.8 \pm 1.30$ \\
\hline & Median (min-max $\left.{ }^{2}\right)$ & $5.38(4.42-6.57)$ & $11.5(9.1-13.7)$ & $61.9(54.4-70.4)$ & $20.9(18.3-24.3)$ \\
\hline
\end{tabular}

$S D^{1}$ : Standard deviation; min-max ${ }^{2}$ : minimum - maximum

Table II: Statistics of Hb variants in BTM patients and their parents.

\begin{tabular}{|c|c|c|c|c|}
\hline & Statistics & $\begin{array}{l}\text { HbF } \\
(\%)\end{array}$ & $\begin{array}{l}\text { HbA } \\
\text { (\%) }\end{array}$ & $\begin{array}{c}\text { HbA2 } \\
\text { (\%) }\end{array}$ \\
\hline \multirow{2}{*}{ Patient(n=30) } & Mean $\pm S^{1}$ & $10.44 \pm 11.54$ & $81.58 \pm 11.05$ & $2.58 \pm 0.32$ \\
\hline & Median (min-max $\left.{ }^{2}\right)$ & $6.01(0.91-55.02)$ & $85.92(39.24-91.51)$ & 2.59 (1.88-3.29) \\
\hline \multirow{2}{*}{ Father(n=29) } & Mean $\pm S^{1}$ & $1.43 \pm 1.60$ & $89.34 \pm 1.44$ & $5.13 \pm 0.51$ \\
\hline & Median (min-max $\left.{ }^{2}\right)$ & $0.94(0.43-8.63)$ & 89.62 (84.41-91.65) & $5.03(4.23-6.34)$ \\
\hline \multirow{2}{*}{ Mother $(n=28)$} & Mean $\pm S^{1}$ & $1.80 \pm 1.90$ & $89.21 \pm 1.90$ & $4.86 \pm 0.68$ \\
\hline & Median (min-max ${ }^{2}$ ) & $1.09(0.40-9.28)$ & 89.84 (82.11-91.46) & $4.88(3.44-6.62)$ \\
\hline
\end{tabular}

$S D^{1}$ : Standard deviation; min-max ${ }^{2}$ : minimum - maximum

Table III: Mutation types we detected, their mechanisms, phenotypic features and frequency.

\begin{tabular}{|c|c|c|c|c|}
\hline Mutation & Mechanism & Type & $\begin{array}{l}\text { Number of the } \\
\text { chromosomes }\end{array}$ & $\begin{array}{c}\text { Percent } \\
\text { (\%) }\end{array}$ \\
\hline $\begin{array}{l}\text { IVS-I-110 (G->A) } \\
\text { (HBB:c.93-21G>A) }\end{array}$ & RNA processing & $\beta^{+}$ & 56 & 46.67 \\
\hline $\begin{array}{l}\text { Codon } 8 \text { (-AA) } \\
\text { (HBB:c.25_26delAA) }\end{array}$ & Frameshift & $\beta^{\circ}$ & 20 & 16.67 \\
\hline $\begin{array}{l}\text { IVS-II-1 (G->A) } \\
(\text { HBB:c.315+1G>A) }\end{array}$ & RNA processing & $\beta^{\circ}$ & 14 & 11.67 \\
\hline $\begin{array}{l}\text { Codon } 44 \text { (-C) } \\
\text { (HBB:c.135delC) }\end{array}$ & Frameshift & $\beta^{\circ}$ & 12 & 10.00 \\
\hline $\begin{array}{l}\text { IVS-II-745 (C->G) } \\
\text { (HBB:c.316-106C>G) }\end{array}$ & RNA processing & $\beta^{+}$ & 6 & 5.00 \\
\hline $\begin{array}{l}\text { IVS-I1-1 (G->A) } \\
(\text { HBB:c.92+1G>A) }\end{array}$ & RNA processing & $\beta^{+}$ & 4 & 3.33 \\
\hline $\begin{array}{l}\text { IVS-I-5 (G->T) } \\
\text { (HBB:c.92+5G>T) }\end{array}$ & RNA processing & $\beta^{+}$ & 4 & 3.33 \\
\hline $\begin{array}{l}-30(T->A) \\
(\text { HBB:c.-80T>A) }\end{array}$ & Transcriptional & $\beta^{+}$ & 4 & 3.33 \\
\hline Total & & & 120 & 100 \\
\hline
\end{tabular}




\section{DISCUSSION}

Severity of illness in BT is related to the degree of imbalance between the alpha globin and nonalpha globin chains ${ }^{14}$. BTT patients are usually asymptomatic and may sometimes show mild anemia. However, BTM patients with transfusion dependency demonstrate severe anemia. In BTM, a reduced $\mathrm{Hb}$ level $<7 \mathrm{~g} / \mathrm{dL}$ and $\mathrm{MCH}<20$ pg levels are observed whereas in BTT there is a decrease in MCV and MCH Levels and an increase in $\mathrm{HbA2}^{4,6}$.

In our study, regarding hematological analysis, following findings were observed in men and women, respectively: $\mathrm{Hb} 13.5 \pm 1.16 \mathrm{~g} / \mathrm{dL}, \mathrm{MCV}$ $63.8 \pm 5.75 \mathrm{fL}, \mathrm{MCH} 21.4 \pm 1.49 \mathrm{pg}$ and $\mathrm{Hb}$ $11.2 \pm 1.05 \mathrm{~g} / \mathrm{dL}, \quad \mathrm{MCV} \quad 62.6 \pm 3.57 \mathrm{fL}, \quad \mathrm{MCH}$ $20.8 \pm 1.30$ (table I). There was a MCV and MCH decrease in parents, and $\mathrm{a} \mathrm{Hb}$ reduction especially in women. Our findings are similar to laboratory findings seen in BTT patients ${ }^{6}$. Concerning hematological analysis in our patients with BTM, Hb $9.20 \pm 1.32 \mathrm{~g} / \mathrm{dL}, \mathrm{MCV}$ $78.93 \pm 5.46 \mathrm{fL}, \mathrm{MCH} 28.32 \pm 1.65$ values were found (table I). Normally, without transfusion, severe hypochromic microcytic anemia is expected in BTM patients. As the patients received erythrocyte suspension transfusions regularly, we observed mild to moderate hypochromic microcytic anemia in our study. For a normal growth and development in patients with BTM, it is recommended to maintain $\mathrm{Hb}$ levels at $9.5 \mathrm{~g} / \mathrm{dL}$ and up through regular transfusion programs ${ }^{15}$. Findings supporting these data were obtained in our study.

According to the type of $\mathrm{BT}$, different $\mathrm{Hb}$ variants are found. $\beta^{0}$-Thalassemia: In homozygous forms $\mathrm{HbA}$ is absent and total $\mathrm{Hb}$ consists of $95-98 \% \mathrm{HbF}$ and $2-5 \% \mathrm{HbA} 2 . \beta^{+}$ thalasssemia: In homozygous or combined $\beta^{0} / \beta^{+}$forms $\mathrm{HbA}$ makes up $10-30 \%$, HbF makes up $70-90 \%$ and $2-5 \% \mathrm{HbA2}^{4}$. In BTT patients HbA2 levels usually are $3.5-5.5 \%$ and rarely exceed $>6 \% 1,16$.
In our study, we found following $\mathrm{Hb}$ variant levels in parents: $\mathrm{HbA} 89.34 \% \pm 1.44, \mathrm{HbF}$ $1.43 \% \pm 1.60$, HbA2 $5.13 \% \pm 0.51$ in men and $\mathrm{HbA}$ $89.21 \% \pm 1.90, \quad \mathrm{HbF} \quad 1.80 \% \pm 1.90, \quad \mathrm{HbA} 2$ $4.86 \% \pm 0.68$ in women (table II). An increase of $\mathrm{HbA} 2$ is expected in BTT patients. Similarly, we observed elevated $\mathrm{HbA} 2$ levels in our work. $\mathrm{Hb}$ variant levels were $\mathrm{HbA} 81.58 \% \pm 11.05, \mathrm{HbF}$ $10.44 \% \pm 11.54, \quad \mathrm{HbA} 2 \quad 2.58 \% \pm 0.32$ in our patients with BTM (table II). As our patients regularly got erythroctye suspension transfusions, our $\mathrm{Hb}$ variant levels aren't similar to those of BTM patients who don't receive transfusions ${ }^{4}$. Nevertheless, the reduced $\mathrm{HbF}$ and elevated $\mathrm{HbA}$ levels observed in our patients indicate that the therapy is carried out regularly.

The different mutation types obtained from our work as well as from molecular studies from different regions of Turkey concerning BT are compared in table IV. For mutation analysis we used DNA sequence analysis methods in our work. Other studies used one or two of the Amplification Refractory Mutation System (ARMS), B-Globin Strip Assay or DNA sequence methods. The DNA sequence method enables the detection of all mutations as the entire gene region of interest can be analysed. Whereas methods like AMRS, Strip Assay enable analysing only limited numbers of mutations and/or bases. Mutations reported as mutations not found or known by methods other than DNA sequence analysis reveals the importance of detection by DNA sequence analysis.

The IVS-I-110 (G->A) mutation was the most frequent observed mutation in our study. Except for the Adıyaman centered work, other studies most frequently found the IVS-I-110 (G$>A)$ mutation (table IV). The most often mutations detected in our study are the IVS-I110 (G->A), codon 8 (-AA), IVS-II-1 (G->A), codon $44(-\mathrm{C})$ mutation types, respectively. In other studies, different authors detected following mutation types: İnce et al. ${ }^{18}$ IVS-I-110 
(G->A), unknown, IVS-I-6 (T->C); Yllmaz ${ }^{19}$ IVSI-110 (G->A), IVS-II-1 (G->A); Ayçiçek et al. ${ }^{20}$ IVS-I-110 (G->A), IVS-I-1 (G->A); Genç et al. ${ }^{21}$ IVS-I-1 (G->A), codon 17 (A->T), IVS-I-110 (G$>A)$, IVS-II-745 $(\mathrm{C}->\mathrm{G})$, codon $8 / 9(+\mathrm{G})$, codon 82/83 (-G); Pehlivan et al. ${ }^{22}$ IVS-I-110 (G->A), unknown, IVS-II-1 (G->A); Guzelgul et al. ${ }^{23}$ IVSI-110 (G->A); Güvenç et al. ${ }^{24}$ IVS-I-110 (G->A); Ozkinay et al.25 IVS-I-110 (G->A); Kurtoğlu et al. ${ }^{26}$ IVS-I $110 \quad(\mathrm{G}->\mathrm{A})$, IVS-I-6 (T->C); Yalçıntepe ${ }^{27}$ IVS-I-110 (G->A), codon 39 (C->T) (table IV). Differences were observed concerning the mutation types between our study and studies of other regions. As for mutation types and frequency our findings were similar to the mutations in Turkey concerning mutation frequencies. Not all mutations could be determined due to methodological differences in some regions. Our studies showed higher similarities with the studies in the Mediterranian region and Aegean than with other regions. Least similarity was found with Edirne and Adiyaman. Due to the difference in the method, it would nevertheless be useful to detect unknown mutations and to increase the study data in order to determine the regional frequency and types of mutations.

Table IV: Mutation types and their frequency in our study and other studies.

\begin{tabular}{|c|c|c|c|c|c|c|c|c|c|c|c|c|}
\hline Mutation & 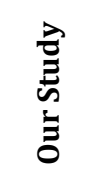 & 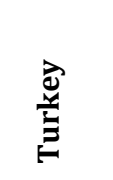 & 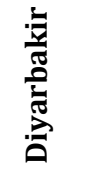 & $\stackrel{\Xi}{E}$ & 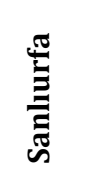 & 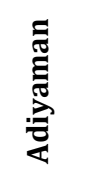 & 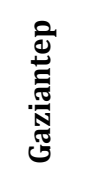 & 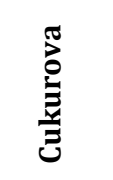 & $\frac{\pi}{\stackrel{7}{7}}$ & 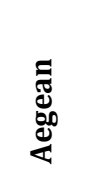 & 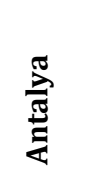 & $\underset{\Xi}{ٍ}$ \\
\hline & $\%$ & $\%$ & $\%$ & $\%$ & $\%$ & $\%$ & $\%$ & $\%$ & $\%$ & $\%$ & $\%$ & $\%$ \\
\hline IVS-I-110(G->A) & 46.67 & 40.88 & 27.8 & 38.89 & 29.1 & 10.7 & 29.1 & 48.08 & 35.14 & 41.7 & 60.8 & 28.6 \\
\hline Codon 8 (-AA) & 16.67 & 4.69 & 11.1 & - & 9.1 & - & 5.6 & 3.85 & 9.15 & 7.7 & 3.1 & 4.1 \\
\hline IVS-II-1 (G->A) & 11.67 & 8.08 & 8.3 & 11.11 & - & 7.1 & 12.3 & 5.77 & 6.43 & 7.2 & 5.2 & 1 \\
\hline Codon $44(-C)$ & 10.00 & 1.78 & $* *$ & 7.41 & 3.5 & 3.6 & 3.1 & 3.85 & 4.95 & 1.3 & 2.1 & 4.1 \\
\hline IVS-II-745 (C->G) & 5.00 & 6.2 & 5.5 & 1.85 & 1.7 & 10.7 & 1.5 & 0.96 & 2.22 & 8.6 & - & 7.1 \\
\hline IVS-I-1 (G->A) & 3.33 & 5.73 & 2.8 & - & 13.9 & 21.4 & 7.7 & 2.88 & 8.66 & 8.9 & 2.1 & 8.2 \\
\hline IVS-I-5 (G->T) & 3.33 & 0.28 & $* *$ & 9.26 & 4.3 & - & $* *$ & 1.92 & 3.71 & 2.2 & - & - \\
\hline$-30(T->A)$ & 3.33 & 4.22 & 2.8 & 9.26 & - & - & 4.6 & 3.85 & 7.42 & 1.0 & 8.2 & - \\
\hline Unknown & - & 2.72 & 27.8 & - & 9.6 & - & 20.9 & 5.77 & - & - & - & - \\
\hline Others & - & 23.86 & 13.9 & 22.22 & 18.2 & 42.9 & 14.9 & 23.07 & 22.27 & 21.4 & 18.5 & 46.7 \\
\hline Total chromosome & 120 & 1064 & 72 & 54 & 230 & 28 & 196 & 132 & 404 & 1171 & 292 & 98 \\
\hline Method * & 3 & 1,3 & 1 & 3 & 2 & 1,3 & 2 & 1,3 & 2 & 3 & 3 & 3 \\
\hline References & & (17) & (18) & (19) & $(20)$ & (21) & (22) & (23) & (24) & $(25)$ & (26) & (27) \\
\hline
\end{tabular}

As BTM patients received regular erythrocyte suspension transfusions, hematological analysis and $\mathrm{Hb}$ variant levels weren't congruent with laboratory data seen in BTM patients. But mean Hb levels of $9.20 \pm 1.32 \mathrm{~g} / \mathrm{dL}$ seen in BTM patients suggests that follow-up and therapy were maintained effectively. Hematological values and $\mathrm{Hb}$ variant levels typical for BTT patients were also found in parents. Similar mutation frequencies were 
observed as seen in Turkey. This study increased the detection percentage of undetermined mutations by the use of DNA sequencing. Thus detection of mutations and determining their effect on disease in multicentered studies with high capacity will contribute to the patient's diagnose and therapy.

Ethics Committee Approval: Ethics committee of the Faculty of Medicine at Dicle University (Decision number: 739/13.11.2012).

Declaration of Conflicting Interests: The authors declare that they have no conflict of interest.

Financial Disclosure: No financial support was received.

\section{REFERENCES}

1. Thein SL. Genetic modifiers of beta-thalassemia. Haematologica 2005; 90: 649-60.

2. Mettananda S, Higgs DR. Molecular basis and genetic modifiers of thalassemia. Hematol Oncol Clin North Am 2018; 32: 177-91.

3. Origa R. $\beta$-Thalassemia. Genet Med 2017; 19: 60919.

4. Cao A, Galanello R. Beta-thalassemia. Genet Med 2010; 12: 61-76.

5. Basak AN. The molecular pathology of betathalassemia in Turkey: The Boğaziçi University experience. Hemoglobin 2007; 31: 233-41.

6. Brancaleoni V, Di Pierro E, Motta I, Cappellini MD. Laboratory diagnosis of thalassemia. Int $\mathrm{J}$ Lab Hematol 2016; 38: 32-40.

7. Viprakasit V, Ekwattanakit S. Clinical classification, screening and diagnosis for thalassemia. Hematol Oncol Clin North Am 2018; 32: 193-211.

8. Jain P, Gupta M, Dua S, Marwah N, Gill M, Sen R. Prevalence of Various Hemoglobinopathies-An Experience from Tertiary Care Centre. Dicle Med J 2019; 46: 269-76

9. Giardine B, Borg J, Viennas E, et al. Updates of the HbVar database of human hemoglobin variants and thalassemia mutations. Nucleic Acids Res 2014; 42: 1063-69. http://globin.cse.psu.edu

10. Çürük MA, Yalın E, Aksoy K. Prevention of hemoglobinopathies in Turkey. Thalassemia Rep 2013; 3: 1-4.

11. Mansilla-Soto J, Riviere I, Boulad F, Sadelain M. Cell and gene therapy for the beta-thalassemias: Advances and prospects. Hum Gene Ther 2016; 27: 295-304.

12. Thein SL. Molecular basis of $\beta$ thalassemia and potential therapeutic targets. Blood Cells Mol Dis 2018; 70: 54-65.

13. Thompson AA, Walters MC, Kwiatkowski J, et al. Gene therapy in patients with transfusiondependent $\beta$-thalassemia. N Engl J Med 2018; 378: 1479-93.

14. Danjou F, Anni F, Galanello R. Beta-thalassemia: From genotype to phenotype. Haematologica 2011; 96: 1573-5.

15. Muncie HL Jr, Campbell J. Alpha and beta thalassemia. Am Fam Physician 2009; 80: 339-44.

16. Ulutaş KT, Şahpaz F, Sarıcı İŞ, et al. A screening study on premarital hemoglobinopathy: Is Kadirli a risk-bearing region for beta-thalassemia in Turkey?. Turk J Biochem 2014; 39: 357-61

17. Altay C.. The frequency and distribution pattern of ß-thalassemia mutations in Turkey. Turk J Haematol 2002; 19: 309-15.

18. Ince $\mathrm{HH}$, Ayyildiz $\mathrm{O}$, Kalkanli S, Batun S, Muftuoglu E. Molecular basis of beta-thalassemia mutations in Diyarbakir in the southeastern region of Turkey. Hemoglobin 2003; 27: 275-8.

19. Yllmaz S. The spectrum of $\beta$-thalassemia mutations in Siirt province, southeastern Turkey. Hemoglobin 2019; 43: 174-81.

20. Ayçiçek A, Koç A, Özdemir ZC, Bilinç H, Koçyiğit A, Dilmeç F. Beta-globin gene mutations in children with beta-thalassemia major from Şanlıurfa province, Turkey. Turk J Haematol 2011; 28: 264-8.

21. Genc A, Tastemir Korkmaz D, Buyukleyla M, Celiker M. Prevalence and molecular analysis of $\beta$ thalassemia in Adiyaman, Turkey. Hemoglobin 2012; 36: 13-8. 
22. Pehlivan S, Okan V, Guler E, et al. Thalassemia mutations in Gaziantep, Turkey. Afr J Biotechnol 2010; 9: 1255-8.

23. Guzelgul F, Seydel GS, Aksoy K. B-globin gene mutations in pediatric patients with $\beta$-thalassemia in the region of Çukurova, Turkey. Hemoglobin 2020; 44: 1-5.

24. Guvenc B, Canataroglu A, Unsal C, et al. $\beta$ thalassemia mutations and hemoglobinopathies in Adana, Turkey: Results from a single center study. Arch Med Sci 2012; 8: 411-4.
25. Ozkinay F, Onay H, Karaca E, et al. Molecular basis of $\beta$-thalassemia in the population of the Aegean region of Turkey: Identification of a novel deletion mutation. Hemoglobin 2015; 39: 230-4.

26. Kurtoğlu A, Karakuş V, Erkal Ö, Kurtoğlu E. $\beta$ thalassemia gene mutations in Antalya, Turkey: results from a single centre study. Hemoglobin 2016; 40: 392-5.

27. Yalçıntepe S. Beta globin mutations in beta thalassemia minor patients in Genetics Diagnosis Center of Trakya University Faculty of Medicine. Ege J Med 2019; 58: 330-5. 